МРНТИ 15.81.99

https://doi.org/10.51889/2020-4.1728-7847.29

\author{
G.N. Kasymzhanova ${ }^{\text {, }}$ A.K.Satova ${ }^{l}$ \\ ${ }^{1}$ Abay Kazakh National Pedagogical University. \\ Almaty, Republic of Kazakhstan
}

\title{
ANALYSIS OF THE STATE OF PARENT-CHILD RELATIONS IN FAMILIES RAISING CHILDREN WITH INTELLECTUAL DISABILITIES
}

\begin{abstract}
Annotation
New trends in special education require the active involvement of parents of children with special educational needs in correctional and developmental work. This article is devoted to the current issues of raising children with intellectual disabilities in the family. The article analyzes the study of the state of parent-child relations in families of raising children with intellectual disabilities. The results of the experimental data obtained show that there is an urgent need for additional training of parents in the correct relationship building in the family for further socialization. The author suggests that the availability of advisory materials covering the process of preparing for interaction with a child, for participating in the implementation of individual developmental programs, for providing a child with corrective assistance at home will help parents to rethink family relationships.

The topic under consideration will be of interest to specialists in the field of correctional pedagogy.

Keywords: children with intellectual disabilities, correctional support, communication, correctional and developmental work, parent-child relations, socialization

\author{
Г.Н.Касымжанова ${ }^{l}$, А.К.Сатова ${ }^{l}$ \\ ${ }^{1}$ Абай атындагы Қазақ ұлттық педагогикалық университеті, \\ Алматы құ. Қазақ̧стан Республикасы
}

\section{ЗИЯТЫ ЗАҚЫМДАЛҒАН БАЛАЛАРДЫ ТӘРБИЕЛЕП ОТЫРҒАН ОТБАСЫЛАРДАҒЫ БАЛА МЕН АТА-АНАНЫҢ ҚАРЫМ- ҚАТЫНАСТАРЫНЫҢ ЖАҒДАЙЫН ТАЛДАУ}

\author{
Аңъдатпа
}

Арнайы білім берудің жаңа трендтері ерекше білім берілуіне қажеттілігі бар балалардың атааналарын түзету-дамыту жұмысына белсенді қосуды талап етеді.Бұл мақала қазіргі кезеңдегі отбасында зияты зақымдалған балаларды тәрбиелеу мәселелеріне арналған. Мақала материалдарында зияты зақымдалған балаларды тәрбиелеп отырған отбасыларға бала мен ата-ананың қарымқатынастарының ерекшеліктерін зерттеуге талдау берілген. Алынған эксперименттік мәліметтердің нәтижелері ата-аналарға одан әрі әлеуметтену үшін отбасылық қатынастарды дұрыс құруға қосымша білім беру қажеттілігі туындағанын көрсетеді. Автор баламен өзара әрекеттесуге дайындық процесін, жеке даму бағдарламаларын жүзеге асыруға қатысуды, балаға үйден түзету жұмыстарының көмегін көрсетуді қамтитын ұсыныс материалдарының болуын, ата-аналарға отбасындағы қарым-қатынасты қайта қарастыруға көмектеседі деп болжайды. Қарастырылып отырған тақырып түзету педагогикасы саласындағы мамандарға қызықты болады.

Tүйінді сөздер: зияты зақылмдалван балалар, түзету құолдау көрсету, құарым-ққатынас, түзету және дамыту жұмысы, ата-ана мен бала қ̧арым-қ̧атынасы, әлеуметтену

\author{
Г.Н.Касымжанова ${ }^{l}$, А.К.Сатова ${ }^{l}$ \\ , Қазахский национальный педагогический университет имени Абая \\ 2. Алматы, Республика Казахстан
}

\section{АНАЛИЗ СОСТОЯНИЯ ДЕТСКО-РОДИТЕЛЬСКИХ ОТНОШЕНИЙ В СЕМЬЯХ, ВОСПИТЫВАЮЩИХ ДЕТЕЙ С НАРУШЕНИЯМИ ИНТЕЛЛЕКТА}

Аннотация 
Новые тренды специального образования требуют активного включения родителей детей с особыми образовательными потребностями в коррекционно-развивающую работу. Данная статья посвящена актуальным на современном этапе вопросам воспитания детей с нарушением интеллекта в семье. В материалах статьи дан анализ изучения состояния детско-родительских отношений в семьях, воспитывающих детей с нарушением интеллекта. Результаты полученных экспериментальных данных показывают, что возникла острая необходимость дополнительного обучения родителей правильному построению отношений в семье для дальнейшей социализации. Автор предполагает, что наличие материалов рекомендательного характера, освещающих процесс подготовки к взаимодействию с ребенком, к участию в реализации индивидуальных развивающих программ, к оказанию ребенку коррекционной помощи в домашних условиях поможет родителям переосмыслить взаимоотношения в семье. Рассматриваемая тема будет интересна специалистам в области коррекционной педагогики

Ключевые слова: дети с нарушением интеллекта, коррекиионная поддержка, коммуникаиия, коррекиионно-развивающяая работа, детско-родительские отношения, социализация

\section{INTRODUCTION}

New trends in special education require the active involvement of parents of children with special educational needs in correctional and developmental work. This provision fully applies to families raising children with intellectual disabilities. The peculiarities of the development of children with intellectual disabilities cause difficulties and problems in family relations, the solution of which is possible only with the interaction of specialists and parents.

A family raising a child with intellectual disabilities is constantly in a stressful situation, not understanding what to do, remains a passive observer, and suffers an ongoing concern for the fate of their child $[1,263]$. One of the reasons lies, in our opinion, in the lack of understanding of the meaning of normal, competent child-parent relations in the family, the lack of methodological support of specialists in the implementation of work to include the family in the correctional and developmental process. Parents need materials of a advisory nature, covering the process of preparing parents for interacting with a child, for participating in the implementation of individual developmental programs, for providing a child with correctional assistance at home, etc. The presence of such materials will help parents to reconsider family relationships. Understanding how much the child will be adapted in family relationships, so much in the future, it will contribute to child's socialization in society, should become an impetus for the formation and development of child-parent relations [2, 195].

\section{MAIN PART}

The first stage of a specialist in working with parents should be associated with identifying and correcting their requests and needs. Observations show that parents' requests often do not correspond to the child's real needs, parents find it difficult to identify the child's leading problems, and are unable to find connections between individual child difficulties. It is especially necessary to emphasize the style of raising a child with intellectual disabilities in a family, parents, in principle, are not aware of how to build relationships with their own child, do not know his/her developmental features, as a result of which difficulties arise in raising a child, understanding needs of child. [3, 76;4,15] That is why parents need education and preparation to participate in corrective support for their child.

The second stage implies specific training of parents to build relationships in the family, with all family members. Work at this stage implies the readiness of all specialists - speech therapists, defectologists, psychologists to get involved in the work of educating parents. Quite often, parents associate their difficulties with establishing interaction with a child in everyday life situations, in building effective communication with a child, in establishing communicative contacts. In this case, the creation of a communicative "pyramid" will serve as an effective tool, that is the algorithm for the formation of the necessary skills for the development of communication - the ability to accept an invitation from an adult to play or communicate; the ability to look in the face and eyes; attention, imitation, sequence, understanding, listening, ability to play, etc.

The task of specialists is to raise the value orientations in the family to a new level, to create optimal microsocial conditions that contribute to the neutralization of non-constructive forms of parent-child behavior, the formation of an active social position regarding the future of own child, etc. 
The family of a child with intellectual disabilities needs specially organized psychological and pedagogical support, which implies active, two-way communication with family members, purposeful work on their inclusion in the correctional support of their child, based on high motivation.

The study of the state of readiness of the family for correctional and developmental work indicates the prevalence of traditional forms of work with parents (homework, parenting meetings, etc.). This is confirmed by the experimental work carried out within the framework of the study on the basis of special (correctional) schools for children with intellectual disabilities. The main methods for identifying the state of parent-child relations in families raising children with intellectual disabilities were questionnaires, oral questioning, and conversations. In total, 80 respondents took part in the experiment, parents raising children with intellectual disabilities from a special (correctional) residential school for children with intellectual disabilities No. 7 in Almaty city, an auxiliary residential school in Semey city.

Parents were offered a questionnaire specially developed by us, consisting of 2 blocks of 10 questions, suggesting the identification of information that is significant for us. The questions of the questionnaire were compiled on the basis of adaptation and interpretation of the questionnaire by L. G. Matveev. The purpose of the questionnaire was to identify the characteristics of parent-child relations in families raising children with intellectual disabilities.

In particular, parents were asked to answer the following questions on the first block:

1. Family composition, permanently living with a child.

2. Full family, single-parent family (mom, dad)

3. Professions of parents.

4. Father's and mother's education.

5. Material situation (satisfactory, unsatisfactory)

6. What is the number of child in the family?

7. What is the relationship between your child in the family and the classroom?

8. Who likes to play with most: peers, younger children, older children, adults?

9. What is your child interested in, what does he or she like to do?

10.Do you feel annoyed with your child?

The second block consisted of the following questions that, in our opinion, allow us to define in some way the family relationship between parents and children, as well as the style of upbringing:

1. Are you and your spouse unanimous in bringing up the child?

2. What is your position in communicating with the child (dominant, on equal terms)?

3. How often do you influence the child - in the form of instructions, explanations, suggestion, persuasion, requests?

4. How often, while doing your business, do you pretend to listen to the child, but not hear him/her? (Often, sometimes, never.)

5. Do you insult the child (in a verbal form) when in conflict with him? (Yes, sometimes, no.)

6. Do you take into account the emotional mood of your child? (Always, sometimes.)

7. How often do you make comments to your child, if he makes mistakes in communication? (Always, sometimes, never.)

8. What methods and how often are used in the family to develop the child's ability to communicate?

9. What difficulties do you face in the process of forming a culture of communication?

10 . What prevents you from fully communicating with your child?

The criteria for assessing the level of relationships between parents and children in the family are three indicators:

- An understanding of the need to develop interpersonal communication skills;

- parents' adherence to the ethics of communicating with their child;

- Parents' compliance with the norms of interpersonal communication between them in the presence of their child.

The analysis of the survey results for the first block revealed the following. Out of 80 Respondents who participated in the survey, the number of full families was 30, the number of families with one parent was 16 , in 2 families as it turned out that parents are deprived of parental rights, the child is brought up by his grandmother (guardianship), so the survey was attended by 48 families. At the same time, in 27 families, in addition to the parents, the older generation represented by grandparents lives. 7 families are raising one child, 29 families have two children, 10 families have three children and 2 families have four and five children. Analyzing the social status of the parents' families, we can draw the following conclusions: out of 
80 respondents 43 have specialized secondary education, 7 have no education (general education school certificate), 25 respondents have higher education (technical and pedagogical), 5 have completed courses and work in the service sector. Professional activity of the interrogated is connected with service sphere (hairdressing salons, cafes) $48 \%, 30 \%$ are involved in production, $22 \%$ carry out labor activity in the sphere of education, health care and social protection. Material situation of families in most cases $97 \%$ of the interviewed persons was noted as satisfactory. In 11 families, a child with intellectual disabilities, as the survey showed, is the firstborn. In 22 families a second child, in 14 families a third child, in 1 family a fourth child.

Answering the question, "What is the relationship of your child in the family and in the classroom", was somewhat difficult for many parents. Almost all parents talked about difficult relationships between children in the family and misunderstanding. At the same time, there were no special problems in the school conditions, according to the parents. In our opinion, this is due to - firstly - the homogeneous contingent of the class, the school, and - secondly - the educational work carried out in a special organization.

As parents' answers to the question "Who does your child like to play with most: peers, younger children, older children, adults?" showed, according to their observations, $64 \%$ of children prefer to play with younger children, $32 \%$ play with peers, and $4 \%$ prefer to play with older children. In our opinion, children with intellectual disabilities prefer playing with younger peers because their cognitive processes and level of intellectual development lag behind those of normal-sized children and, accordingly, children feel more comfortable playing with younger children.

Analysis of responses concerning children's interests revealed that children like to play, draw, and sculpt, etc. No parents mentioned any educational activities. In a more detailed oral survey related to drawings and handicrafts, parents were not always able to name the best drawing and handicraft of a child. Usually school handicrafts and drawings were named. This situation is apparently due to the fact that most of the time children were in the system of the school - boarding school (from Monday to Friday) and only on weekends they were at home.

We received sharp answers to the question "Do you feel displeased with your child? Only 17\% of parents answered "sometimes". The rest of parents answered "no". Answers to the additional question, "in what situations did your discontent appear", were received: "when the child did not fulfill the assignment", "did not do what was asked".

The second block of questions was focused on identifying the state of child-parental relations in the family.

Answers to the first question of the second block showed ambiguity of approaches to education in families. A number of parents $(68 \%)$ believe that a child should be brought up strictly, without excesses. $12 \%$ of parents believe that their child has problems and, therefore, it is necessary to make certain "indulgences" to the peculiarities of behavior, and $8 \%$ of parents believe it is necessary to limit the child in communication in order not to cause negative reactions from others. Accordingly, the answers to the second question (based on the answers to the first one) were also expected of us. The dominant position in communicating with a child was noted by $87 \%$ of parents. In a personal conversation when we were asked to reveal the concept of "dominant", parents said they decide what to do and make up the daily routine, thus determining the child's lifestyle in its entirety. $13 \%$ believed they have an "equal" relationship and they listen to the child and take into account his or her opinions and desires.

Answers to the question "how often do you influence a child - in the form of instructions, explanations, suggestion, persuasion, and requests" were interesting. As it turned out, parents use all kinds of influences; none of the interviewed respondents adhered to any one type of influence. Parents explained that everything depends on the situation; in some cases, request, suggestion, and somewhere direct instructions are used. One parent revealed they sometimes use both "blackmail" and some "threats" because the child eventually fails to get what they want.

The received answers to question 4 allowed us to draw the following conclusions. Only $25 \%$ of parents are really attentive to their child, listen and hear him/her. However, after thinking more deeply about the answer, they mentioned that there are situations when they pretend to listen to their child and not hear $\mathrm{him} / \mathrm{her}$. $63 \%$ of parents reported that such situations occur frequently and they do not listen to what the child says while doing their job. $12 \%$ of parents said they sometimes allow such situations, but still mostly try to listen to the child and respond.

The fifth question, which demanded a very truthful answer from parents, showed, 
how many parents are able to be open and honest with themselves and their child. Only 7\% (8 parents) were able to honestly say they insulted a child in a verbal manner. In a situation of disobedience, parents could not stand it, shouted at the child, could call him not quite loyal words. Then there was remorse, but situations are repeated. In a personal conversation, the parents justified the difficult situation at work, fatigue, constant stressful environment in the house, dissatisfaction with the upbringing of the child with intellectual disabilities in the family. $23 \%$ of respondents answered "sometimes" only in cases when the child did not behave adequately, and $70 \%$ of parents gave a negative answer.

We were interested in the answer to the question about taking into account the emotional mood of the child. Realizing that the emotional state of children with intellectual disabilities is not stable, children, as a rule, are disintegrated and prone to rapid mood changes, wanted to hear true answers to question $6.68 \%$ of parents answered that they always take into account a child's emotional state of mind. In an additional conversation we tried to find out what this consideration is. Parents answered that when a child is excited, they try to calm him down, give him something he likes, or switch his attention. If a child is overwhelmed, find out what happened and who is offended. $32 \%$ of parents responded that they don't always take into account a child's emotional state just by not paying attention.

Answering the question "How often do you make comments to a child, if he makes mistakes in communication? (Always, sometimes, never.)", we received the following answers. $48 \%$ of survey participants gave the answer "always". From $67 \%$ of respondents we heard the answer "sometimes", $15 \%$ of parents answered "never". When asked an additional question as you understand the expression "mistakes in communication," parents responded that it is "improper behavior on the street, on a walk, at school with peers and adults.

The answer to the question, "What methods and how often are used in the family to develop a child's ability to communicate" made parents think. The answers received made it clear that parents are not familiar in principle with the techniques for developing the child's ability to communicate. Although parents tried to list the following methods: discussions, joint holidays. However, this was the end of the list. As shown by the parents' answers, the main difficulties in applying the techniques are connected with the lack of knowledge about the techniques and target goals - this was pointed out by $92 \%$ of interviewed parents. Different training sessions, according to parents, should remove the difficulties in the application of techniques at home. Parents expressed a desire to get acquainted with the proper conduct of communicative games and exercises, to listen to lectures. on topics related to the situation of communication, solutions to "difficult" situations, etc.

Difficulties encountered by parents in the process of communication are primarily, as noted by $87 \%$ of respondents, related to the peculiarities of the child's development, with the rapid forgetting of what the parent said to the child, not wanting the child to remember the rules of behavior, with frequent diseases of the child, with limited communication with normal peers who do not accept a special child in their circle of communication, etc. $13 \%$ of parents said they did not notice any difficulties. They mentioned that the child is doing well in terms of communication.

The last question, in some ways duplicated the ninth question. From our side it was done intentionally, in order to confirm once again the understanding of parents of the peculiarities of communication of their child. Comparing the answers to the ninth and tenth questions, it is necessary to note approximately the same answers, but already $93 \%$ indicated the features of their child, the presence of some lag in development. At the same time, the survey of this category of respondents showed that they have a common, often very superficial, understanding of their child's communication problems. $7 \%$ were unable to answer this question because they thought their children had no difficulties.

In addition to the survey, we analyzed 240 statements made by parents during the personal conversation and oral survey. Parents, for the most part, understand the need to include them in the correctional work in order to properly develop their child's communication skills and to include them in society on the one hand. On the other hand, parents want to improve parent-child relations in the family and learn to understand their child's needs. Parents have expressed their willingness to learn.

According to the survey results, we have conditionally allocated three groups of parents.

The basis for this division were the following indicators: interest in inclusion in the correction and development work; desire to master the skills and abilities to use the methods of development of communication at home; vision of the need to improve parent-child relations; awareness of the need for targeted training of the child to communicate; ability to positively influence the child; ability to interest the 
child; understanding the potential of the family in the upbringing of the child; understanding the peculiarities and peculiarities of the child, the ability to apply the difference in his or her life.

The first group was made up of parents with a fairly high understanding of their child's features and the need to properly build parent-child relationships. Their understanding was characterized by depth, that is, they were able to consciously and adequately evaluate their child's state, level of development, and, what is especially valuable for us, vision of their child's problems and the problems of the child's relationships both in the family and in the collective. Parents described in sufficient detail the difficulties of their child's communication, correlated these features with age and individual development, tried to influence the child, read special literature, watched various videos, consulted with teachers, psychologists, educators, and watched their child. Parents clearly understood and represented the child's future education and profession. The number of such parents was $13 \%$ of all respondents.

The second group consisted of parents with an average level of orientation in the problem of their child with intellectual disabilities, as well as a lack of understanding of the meaning of home education. Parents had a general understanding of their child's characteristics; the main emphasis in their upbringing was on school, although parents did not deny the need for home education, but more often, education was associated with going to the cinema, entertainment centers, and walks. Parents did not think much about their child's future or about the need to prepare him or her for social inclusion. According to the analysis results, $72 \%$ of the interrogated were assigned to the second group.

Parents of the third group were characterized by a relatively low level of understanding that their child requires special methods of upbringing and training and the need to build specific relationships in the family. Parents lacked understanding of their child's future and difficulties in entering society and gaining a profession. Parents did not have any attempts to establish proper relations with their child or with the school. They were indifferent to their own activities in the formation of child-parental relations in the family, explaining that their family has normal relationships. This group was represented by $15 \%$ of the respondents.

In general, as the survey showed, it is very rare that parents of children with intellectual disabilities understand the need to build a correct and close relationship with the child in the family. However, for the most part, parents do not deny the need and importance of building communication skills in the child, precisely for the purpose of his further socialization. But at the same time, parents do not know the methods of work, as they are not trained in these technologies. This indicates the need to organize special training for parents. Thus, our survey among parents showed that parents of children with intellectual disabilities have superficial information about the peculiarities of their child's development, about the peculiarities of communication of a child with intellectual disabilities, the possibilities and methods of work at home. In principle, the methods of forming communication are not used by parents.

Among parents there is a lack of awareness of the need to teach children to communicate in society. There is an informative lack of parents' awareness of organizational, substantive, and methodological aspects of teaching their children.

Our research suggests that at this stage there is an urgent need to supplement the content of education for children with intellectual disabilities in order to further their socialization in society.

\section{CONCLUSION}

Thus, the development of a program for parents to establish child and parental relations in the family could serve as a continuation of the research. It should be noted that at present, various programs have been developed to work with families raising a child with developmental problems [5,102]. However, given the growing complexity of the social sphere on the one hand and the complex structure of the defect in children with intellectual disabilities on the other hand, we believe that additional development of programs for parents is needed. At the same time, the program for parents raising children with intellectual disabilities should contain several specific tasks and specific, clear methods of work with available instructions on how to do these tasks, and be small, accessible and understandable in content. In order to accomplish the tasks, it is necessary to specify the techniques to be used in a family environment. These may be different games, daily tasks. Parents need to describe in great detail how to use these games, the time, frequency of use, who will perform the task, what to do if there are difficulties in performing the exercise. In our opinion, the program for parents should not be long so that they do not lose interest. The program should be capacious and designed for no more than 1-3 months. The main condition should be parents' interest and desire to work in the program; for this purpose it is necessary to find out at the first meetings what the main difficulties the family and the child have. The parents' requests should be discussed in terms of their 
adequacy and importance. The program should substantiate the real difficulties and their causes. This will be helped by observing the child in the school team, the interaction between parents and children, and familiarization with documentation and characteristics of the child.

The program for parents should be a small part of the child's individual development program; in fact, the program should be aimed at further socialization of the child in society. Several parenting programs can be developed throughout the whole correction process. This will help maintain parents' interest in the correctional work. The program is a kind of response to requests from parents. The main part of the program is parent education. Specialists in the classes show, teach, and form skills, which a parent should master. In this case, the forms of training can be quite different. These are psychological trainings, seminars, webinars, case studies, exchange of experience, etc. Specialists in our opinion, it is necessary to introduce a special task for parents, focused on parental education.

The ability of specialists to develop such programs for the family will facilitate the inclusion of parents in the correction process, the establishment of intra-family relationships, the formation of new values and constructive forms of behavior. The correctional work with a child will become a continuous process and there will be opportunities to expand the range of correctional services for a child through participation in the family. In the future, this will contribute to the formation of a child's ability to establish relationships in a team and, as a result, to the child's socialization in society. 